\title{
THE EFFECT OF ADDITIVE WITH FOAM AGENT AND COCONUT SHELL ON LIGHTWEIGHT CONCRETE
}

\author{
Fikki Efendi \\ Faculty of Engineering \\ Narotama University Surabaya \\ fikki.efendi@gmail.com \\ Fredy Kurniawan \\ Faculty of Engineering \\ Narotama University Surabaya \\ fredy@narotama.ac.id \\ Diah Ayu Restuti Wulandari \\ Faculty of Engineering \\ Narotama University Surabaya \\ diah.wulandari@gmail.ac.id
}

\begin{abstract}
Concrete houses have a higher social and economic status. This study provides another consideration for the selection of building materials (Wonorahardjo, 2008). There are several ways that can be used to make concrete lighter, including using lightweight aggregates, substituting coarse aggregates with foam agents, adding coconut shells and additives where coconut shell waste has not been used optimally. In this research, a lightweight concrete mixture made from additives $5 \mathrm{M}$ additive, foam agent and coconut shell using $3 \mathrm{~kg}$ cement composition. While the $5 \mathrm{M}$ additives variation of $3 \%, 5 \%, 10 \%, 15 \%$ of cement, 15 milliliters of foam agent and coconut shell of $1 \%$, with consideration of the specimens for 28 days not soaked non-curing. The test specimen is made with a size of $15 \times 30 \mathrm{~cm}$. This study is to determine the weight, compressive strength of the lightweight concrete produced. The results of research on the use of additional $5 \mathrm{M}$ additives, foam agents and coconut shells cause concrete to be lighter and compressive strength decreases. The weight of light concrete at 28 days not soaked is $775 \mathrm{~kg} / \mathrm{cm} 3$, while the quality of concrete is $22 \mathrm{~kg} / \mathrm{cm} 2$.
\end{abstract}

Keywords Lightweight concrete, mix design, compressive strength, additive, foam agent, coconut shell

\section{INTRODUCTION}

asically, concrete has a property of weak to tensile, strong to compressive and has a composition of cement, sand, aggregate, and water (Asroni, 2010). Indonesia is a country with 3,585,599 ha of coconut plantations in 2015 (2015) with a production value of 2,920,665 tons. In the industrial sector, coconuts are processed only in the coconut flesh and part of it is waste. One of the coconut wastes is coconut shell which has soft, light, absorbs water, wood texture, coconut shell has chemical components such as cellulose, lignin, pentosan, extractive solvent, uronic anhydrite, ash, nitrogen and water, then coconut shell has quality as an aggregate.

Lightweight concrete is a mixture of cement, water, aggregate with certain added ingredients (admixture), namely by making gas or air bubbles in a mortar that causes many air pores in the concrete (Husin and Setiaji, 2008). One additive chemical product for research using additive 5iton additive products produced by PT. Additon Karya Sembada. 


\section{Raw material}

\section{Cement}

cement is an ingredient that acts as an aggregate binder, if mixed with portland cement it is made through several steps, so it is very smooth and has both adhesive and cohesive properties. Cement is obtained by burning carbonate or limestone and argillaceous (containing aluminia) with a certain ratio. The material is mixed and burned at a temperature of $1400^{\circ} \mathrm{C}-1500^{\circ} \mathrm{C}$ and becomes clinker. After that it is cooled and mashed until it is like powder. Then casts or calcium sulfate (CaSO4) are added approximately $2-4 \%$ percent as a binding time control material. Other added ingredients are sometimes also added to form special cement such as calcium chloride to make the cement harden quickly. Cement is usually packed in $40 \mathrm{~kg} / 50 \mathrm{~kg}$ bags (Sutikno, 2003: Menurut SIl 0031-81 semen portland dibagi menjadi five types, as follows:

Type I: Cement for general use, does not require special requirements.

Type II: Cement for sulfate-resistant concrete and has a moderate hydration heat. Type III: Cement for concrete with high initial strength (fast hardening).

Type IV: Cement for concrete that requires low hydration heat.

Type V: Cement for concrete which is very resistant to sulfate.

\section{Aggregate}

Is a mineral grain that is the result of natural disintegration of rocks or also the result of a stone-breaking machine by breaking down natural stones. Aggregate is a filler in concrete, however the role of aggregate in concrete is very important. According to SK-SNI-T-15-1990-03 the roughness of sand is divided into four groups according to its gradation, namely fine sand, rather fine, somewhat coarse and coarse. Generally sand has fine modulus of grains between 1,5 to 3,8 .

The sand used in the concrete mix must meet the following requirements:

Fine sand consists of sharp and hard grains. This is because with the sharp form of sand, the link between the aggregates will be better, while the hard nature to produce hard concrete as well.

1. The grains must be eternal. This eternal nature means that the sand is not easily destroyed by the influence of the weather, so the resulting concrete is also resistant to weather influences.

2. Sand should not contain mud more than $5 \%$ of its dry weight, because the existing mud will block the bond between the sand and cement paste, if the concentration of mud is high, the resulting concrete will be of low quality.

3. Sand must not contain too much organic matter.

Table 1 Fine Aggregate Gradation

\begin{tabular}{|c|c|c|c|c|}
\hline Sieve Hole (mm) & \multicolumn{4}{|c|}{$\begin{array}{c}\text { Percentage of Granular Material } \\
\text { The Sifters }\end{array}$} \\
\cline { 2 - 5 } & $\begin{array}{c}\text { Daerah } \\
\text { I }\end{array}$ & $\begin{array}{c}\text { Daerah } \\
\text { II }\end{array}$ & $\begin{array}{c}\text { Daerah } \\
\text { III }\end{array}$ & $\begin{array}{c}\text { Daerah } \\
\text { IV }\end{array}$ \\
\hline 10 & 100 & 100 & 100 & 100 \\
4,8 & $90-100$ & $90-100$ & $90-100$ & $95-100$ \\
2,4 & $60-95$ & $75-100$ & $85-100$ & $95-100$ \\
1,2 & $30-70$ & $55-90$ & $75-100$ & $90-100$ \\
0,6 & $15-34$ & $35-59$ & $60-79$ & $80-100$ \\
0,3 & $5-20$ & $8-30$ & $12-40$ & $15-50$ \\
0,15 & $0-10$ & $0-10$ & $0-10$ & $0-15$ \\
\hline
\end{tabular}

Source : Tjokrodimuljo, (1996)

Information : 
Area I: Coarse sand

Area II: Sand is rather rough

Area III: Sand is rather fine

Region IV: Fine Sand

The coarse aggregate that can be used must meet the requirements (Tjokrodimulyo with cement water into a paste. With the process of time and heat, the chemical reaction due to a mixture of water and cement produces the cement pavement properties. The discoverer of cement (Portland Cement) was Joseph Aspdin in 1824, a English masons, called Portland cement, because initially the cement produced had the same color as the natural clay on Portland Island

\section{Additive Admixture}

Admixture is an additional material for mixing concrete that is processed before or during the mixing process, the admixture function is to modify concrete characteristics with the aim of improving concrete workability, regulating cement water factor in fresh concrete, reducing the use of cement, preventing segregation and bleeding, regulating the binding time of stirring concrete, increase the strength of hard concrete, improve the waterproof properties of hard concrete and improve the durable properties of hard concrete including resistance to chemicals, resistance to friction and others.

\section{Coconut Shell}

Coconut shell; Coconut shell is waste (residual processing) from households or industries that use coconut as the main ingredient. Its presence is widely found around us, and its use is mostly limited to firewood. According to (Soroushian and Bayasi, 1987) and according to (Tjokrodimuljo, 1990).

\section{Water for}

making concrete must meet the minimum requirements as drinking water that is fresh, odorless, and does not contain ingredients that can damage concrete, such as oil, acids, alkali, salt or other organic materials which can damage concrete or reinforcement (SNI 03-2847-2002, Procedures for Calculating Concrete Structures for Buildings). In addition to the binding reaction, it can also be used for maintenance after the concrete has been poured. Curing water must have a higher requirement than water for making concrete. The acidity must not be $\mathrm{pH}>6$, nor should it contain too little lime. The use of water for concrete should meet the following water requirements, (Kardiyono Tjokrodimulyo, 1992): 1. Does not contain mud or other floating objects more than $2 \mathrm{gr} /$ liter. 2. Does not contain salts which can damage concrete (acids, organic substances) more than $15 \mathrm{gr} /$ liter. 3 . Does not contain Chloride $(\mathrm{Cl})$ more than $0.5 \mathrm{gr} /$ liter. 4. Does not contain sulfate compounds more than 1 gram / liter.

\section{RESEARCH METHODOLOGY}

Processing coconut shell as an aggregate, first cut coconut shell with size $<10 \mathrm{~cm}$. The materials used include, among others, coconut shells that have been processed, Foam Agent and Additive Additon 5M that is used is the "Additon" brand. Planning the proportion of concrete mix material using a mixture selection plan based on SNI 7656: 2012 with the results as a reference for normal concrete that is developed into innovation concrete

Table 2 Test Object Formula

\begin{tabular}{cccccccc}
\hline \multirow{2}{*}{ Test Objects } & Cement & Sand & Gravel & $\begin{array}{c}\text { Additon } \\
5 \text { M }\end{array}$ & $\begin{array}{c}\text { Foam } \\
\text { Agent }\end{array}$ & $\begin{array}{c}\text { Coconut } \\
\text { shell }\end{array}$ & $\begin{array}{c}\text { w/c } \\
\text { Ratio }\end{array}$ \\
\cline { 2 - 7 } & $(\mathrm{kg})$ & $(\mathrm{kg})$ & $(\mathrm{kg})$ & $($ milliliter $)$ & $(\Lambda)$ & $(\mathrm{kg})$ & $(1)$ \\
\hline
\end{tabular}




\begin{tabular}{|c|c|c|c|c|c|c|c|}
\hline $\begin{array}{c}\text { Concrete } \\
\text { K.300 }\end{array}$ & $4,13 \mathrm{~kg}$ & $\begin{array}{c}6,81 \\
\mathrm{~kg}\end{array}$ & $\begin{array}{c}10,21 \\
\mathrm{~kg}\end{array}$ & - & - & - & 0,52 \\
\hline ADBK 1 & $3 \mathrm{~kg}$ & $\begin{array}{c}3,25 \\
\mathrm{~kg}\end{array}$ & $0 \%$ & $\begin{array}{c}5 \% \\
\text { from } \\
\text { cement }\end{array}$ & 15 mililiter & $\begin{array}{c}1 \% \\
\text { from sand }\end{array}$ & 0,3 \\
\hline ADBK 2 & $3 \mathrm{~kg}$ & $\begin{array}{c}3,25 \\
\mathrm{~kg}\end{array}$ & $0 \%$ & $\begin{array}{l}10 \% \\
\text { from } \\
\text { cement }\end{array}$ & 15 mililiter & $\begin{array}{c}1 \% \\
\text { from sand }\end{array}$ & 0,3 \\
\hline ADBK 3 & $3 \mathrm{~kg}$ & $\begin{array}{c}3,25 \\
\mathrm{~kg}\end{array}$ & $0 \%$ & $\begin{array}{l}15 \% \\
\text { from } \\
\text { cement }\end{array}$ & 15 mililiter & $\begin{array}{c}1 \% \\
\text { from sand }\end{array}$ & 0,3 \\
\hline ADBK 4 & $3 \mathrm{~kg}$ & $\begin{array}{c}3,25 \\
\mathrm{~kg}\end{array}$ & $0 \%$ & $\begin{array}{c}3 \% \\
\text { from } \\
\text { cement }\end{array}$ & 15 mililiter & $\begin{array}{c}1 \% \\
\text { from sand }\end{array}$ & 0,3 \\
\hline
\end{tabular}

Source: Narotama University laboratory test results.

The making of test specimens is made of 30 pieces in cylindrical shape, each made with two variations of the test specimen. Test specimens in cylindrical shape which has a side of $15 \times 30 \mathrm{~cm}$. At the mixing stage, Motar mixed with $5 \mathrm{M}$ addition is stirred until it is homogeneous, then makes up the Foam Agent that has been mixed with water until it becomes foam, when making foam must be considered the level of viscosity of the foam, after the foam becomes the next step mixing the foam agent with the mohtar. finally with coconut shells and stirring until concrete is mixed. After fresh concrete reaches homogeneous. At the treatment stage the test specimens were carried out by the non-curing method. Compressive strength testing is performed on specimens aged 7, 14 and 28 days. Compressive strength testing is carried out at the Mechanical and Concrete Laboratory of Civil Engineering, Narotama University, Surabaya. The relationship between quality and weight is the equation of compressive strength ( $\mathrm{fc}$ ') divided by specific gravity $\left(\mathrm{kg} / \mathrm{cm}^{3}\right)$.

\section{RESULTS AND DISCUSSION}

In compressive strength testing, the compressive strength results are obtained as follows;

Table 3. Results of Compressive Strength and Specific Gravity Tests

\begin{tabular}{|c|c|c|c|c|c|c|c|c|c|}
\hline \multirow{2}{*}{ No. } & \multirow{2}{*}{\multicolumn{2}{|c|}{ Concrete type }} & \multicolumn{3}{|c|}{$\begin{array}{l}\text { Weight } \\
\text { Average }\end{array}$} & \multicolumn{3}{|c|}{$\begin{array}{l}\text { Compressive Strength } \\
\text { Average }(\mathrm{kg} / \mathrm{cm} 2)\end{array}$} & \multirow{2}{*}{$\begin{array}{c}\text { Ratio } \\
\text { Fc'/Weight } \\
28 \text { Days }\end{array}$} \\
\hline & & & $\begin{array}{l}7 \\
\text { Hari }\end{array}$ & $\begin{array}{l}14 \\
\text { Hari }\end{array}$ & $\begin{array}{c}28 \\
\text { Hari }\end{array}$ & $\begin{array}{c}7 \\
\text { Hari }\end{array}$ & 14 Hari & $\begin{array}{c}28 \\
\text { Hari }\end{array}$ & \\
\hline \multirow{2}{*}{1.} & \multirow{2}{*}{$\begin{array}{l}\text { CONCRETE } \\
\text { NORMAL }\end{array}$} & CR & 12.311 & 12.111 & 12.021 & 203 & 275 & 313 & 7,2 \\
\hline & & CR & 12.421 & 12.127 & 12.053 & 205 & 278 & 316 & 7,1 \\
\hline \multirow{2}{*}{2.} & \multirow{2}{*}{ ADBK 1} & NC & 4.287 & 4.141 & 4.112 & 7 & 10 & 11 & 70,54 \\
\hline & & $\mathrm{NC}$ & 4.377 & 4.156 & 4.119 & 8 & 11 & 12 & 64,75 \\
\hline 3. & ADBK 2 & $\mathrm{NC}$ & 4.182 & 4.102 & 4.041 & 11 & 15 & 16 & 47,62 \\
\hline
\end{tabular}




\begin{tabular}{|c|c|c|c|c|c|c|c|c|c|}
\hline & & NC & 3.992 & 3.891 & .3 .819 & 11 & 15 & 16 & 45,06 \\
\hline \multirow{2}{*}{4.} & \multirow{2}{*}{ ADBK 3} & NC & 4.331 & 4.143 & 4.103 & 11 & 15 & 16 & 48,37 \\
\hline & & NC & 4.426 & 4.215 & 4.101 & 11 & 15 & 16 & 48,37 \\
\hline \multirow{2}{*}{5.} & \multirow{2}{*}{ ADBK 4} & NC & 4.394 & 4.161 & 4.105 & 14 & 20 & 22 & 35,22 \\
\hline & & NC & 4.419 & 4.221 & 4.098 & 14 & 20 & 22 & 35,13 \\
\hline
\end{tabular}

Source: Narotama University laboratory test results.

Seen from the summary table of the results of the density of normal concrete and lightweight concrete with cylindrical test specimens at the age of 28 days, and the results of compressive strength of norm concrete and lightweight concrete with mix design using cement, sand, $5 \mathrm{M}$ addition, foam agent, coconut shell with lightweight concrete not soaked (non-curing) maintenance. In normal concrete at 28 days the average density is 2274 $\mathrm{kg} / \mathrm{cm}^{3}$, and the normal concrete compressive strength at 28 days is $316 \mathrm{~kg} / \mathrm{cm}^{2}$, for the ratio $\mathrm{fc}^{\prime} /$ weight at 28 days at 7.2.

In lightweight concrete (ADBK 1), the treatment is not soaked (non-curing) specific gravity of $777 \mathrm{~kg} / \mathrm{cm}^{3}$, has a $65.88 \%$ decrease compared to normal concrete and with a compressive strength of $12 \mathrm{~kg} / \mathrm{cm}^{2}$, has decreased $89.79 \%$ of the compressive strength of concrete normal, whereas the ratio fc//weight is lightweight concrete (ADBK 2) not soaked (non-curing) 70.54 .

In lightweight concrete (ADBK 2) the treatment is not soaked (non-curing) concrete density $762 \mathrm{~kg} / \mathrm{cm}^{3}$, decreased $68.31 \%$ from normal concrete and with a compressive strength of $16 \mathrm{~kg} / \mathrm{cm}^{2}$, decreased $94.94 \%$ of the compressive strength of concrete normal, whereas the ratio $\mathrm{fc}^{\prime} /$ weight is lightweight concrete (ADBK 2) not soaked (non-curing) 47.62.

In lightweight concrete (ADBK 3 ) the treatment is not soaked (non-curing) concrete density of $774 \mathrm{~kg} / \mathrm{cm} 3$, decreased $65.95 \%$ of normal concrete and with compressive strength $16 \mathrm{~kg} / \mathrm{cm}^{2}$, decreased $94.94 \%$ of concrete compressive strength normal, whereas the ratio $\mathrm{fc} /$ weight is lightweight concrete (ADBK 3 ) not soaked (non-curing) 48.37.

In lightweight concrete (ADBK 4) the treatment is not soaked (non-curing) concrete density of $775 \mathrm{~kg} / \mathrm{cm}^{3}$, decreased $66 \%$ from normal concrete and with compressive strength of $22 \mathrm{~kg} / \mathrm{cm}^{2}$, decreased $93.04 \%$ of the compressive strength of normal concrete, While the $\mathrm{fc}^{\prime} /$ weight ratio is lightweight concrete (ADBK 4) not soaked (non-curing) 35.22.

Table 3 Average Gravity and Compressive Strength Average age of 28 days

\begin{tabular}{|c|c|c|c|c|c|}
\hline $\begin{array}{l}\text { Test } \\
\text { object }\end{array}$ & Age & Care & $\begin{array}{c}\text { Specific } \\
\text { gravity } \\
\text { Average } \\
\left(\mathrm{kg} / \mathrm{cm}^{3}\right)\end{array}$ & $\begin{array}{c}\text { Compressive } \\
\text { Strength } \\
\text { Average } \\
\left(\mathrm{kg} / \mathrm{cm}^{2}\right)\end{array}$ & $\begin{array}{l}\text { fc' } \\
\text { Weight }\end{array}$ \\
\hline \multirow{2}{*}{ Normal } & 28 & CR & 12.021 & 313 & 7,2 \\
\hline & 28 & $\mathrm{CR}$ & 12.053 & 316 & 7,1 \\
\hline \multirow{2}{*}{ ADBK 1} & \multirow{2}{*}{28} & CR & 4.112 & 11 & 70,54 \\
\hline & & NC & 4.119 & 12 & 64,75 \\
\hline \multirow{2}{*}{ ADBK 2} & \multirow{2}{*}{28} & $\mathrm{NC}$ & 4.041 & 16 & 47,62 \\
\hline & & $\mathrm{NC}$ & .3 .819 & 16 & 45,06 \\
\hline \multirow{2}{*}{ ADBK 3} & \multirow{2}{*}{28} & $\mathrm{NC}$ & 4.103 & 16 & 48,37 \\
\hline & & $\mathrm{NC}$ & 4.101 & 16 & 48,37 \\
\hline \multirow[b]{2}{*}{ ADBK 4} & 28 & NC & 4.105 & 22 & 35,22 \\
\hline & 28 & NC & 4.098 & 22 & 35,13 \\
\hline
\end{tabular}

Source: Narotama University laboratory test results 
In Table 4, the highest value of quality with specific gravity is obtained in the specimen (ADBK4) with an average compressive strength of $22 \mathrm{~kg} / \mathrm{cm}^{2}$ and a specific gravity of 4,105 $\mathrm{kg} / \mathrm{cm}^{3}$.

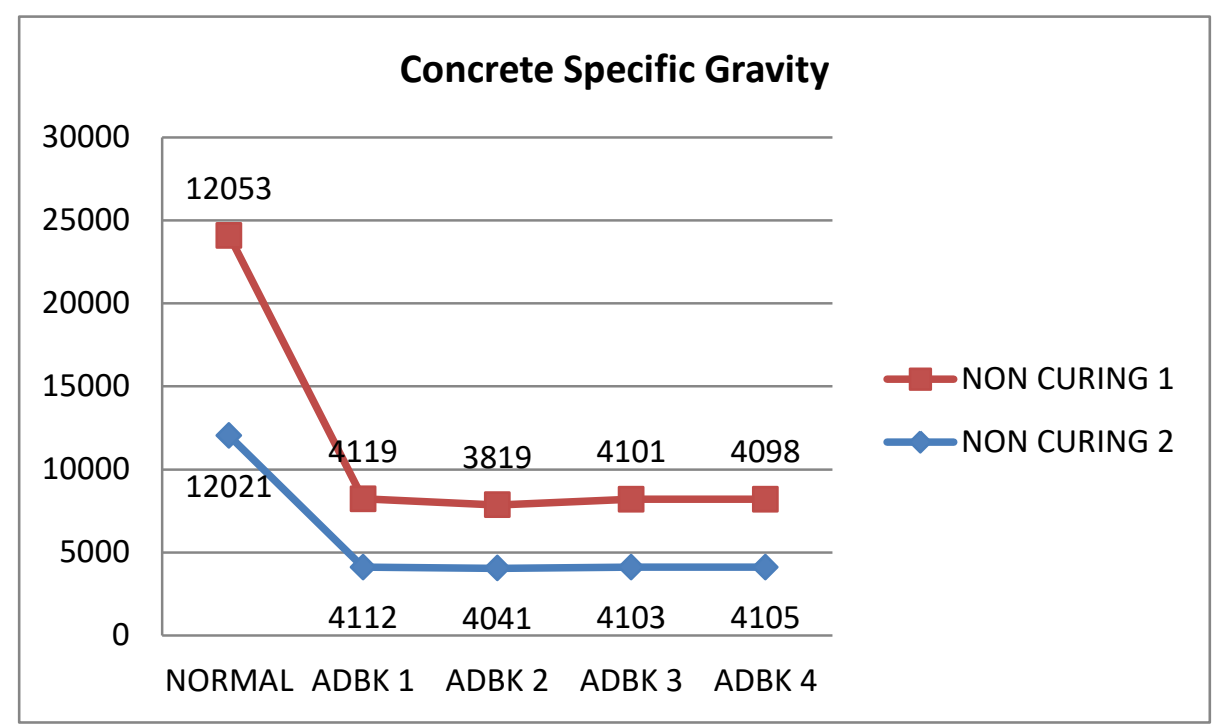

Picture 1. Concrete Specific Gravity at 28 days

In Table 4, the highest value of quality with specific gravity is obtained in the specimen (ADBK4) with an average compressive strength of $22 \mathrm{~kg} / \mathrm{cm} 2$ and a specific gravity of 773 $\mathrm{kg} / \mathrm{cm} 3$.

\section{CONCLUSIONS}

Based on the results of research and discussion, the following conclusions can be drawn:

1. The results of the cylinder compressive strength test that have been carried out that the composition of the material that is done with the mix design that is addition $5 \mathrm{M}$, foam agent, coconut shell can affect the compressive strength of lightweight concrete and the specific gravity of light concrete is very significant. The more mixing of the material with lightweight concrete affects the compressive strength of lightweight concrete and the weight of concrete in the concrete age of 28 days. net compressive strength of normal age 28 days decreased by compressive strength $96.20 \%$ of the compressive strength of normal concrete of $313 \mathrm{~kg} /$ $\mathrm{cm}^{2}$.

2. The compressive strength of concrete is getting weaker along with the greater use of addition $5 \mathrm{M}$, foam agent, coconut shell with the method not soaked. The highest compressive strength of lightweight concrete is achieved by (ADBK 4) concrete with cement content of $3 \mathrm{~kg}$, sand $3.25 \mathrm{~kg}$, addition $5 \mathrm{M} \mathrm{3} \%$, foam agent 15 milliliters, coconut shell $1 \%$ at $22 \mathrm{~kg} / \mathrm{cm}^{2}$. Regarding increasing the composition of Additon 5M, Foam Agent, Coconut Fiber also affects the quality of lightweight concrete.

3. Weight test results of lightweight concrete not immersed, can be seen the weight of

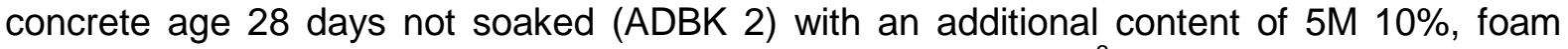
agent 15 milliliters, coconut shell $1 \%$ with a weight of $721 \mathrm{~kg} / \mathrm{cm}^{3}$.

In order to produce research that will later become better in further research the authors suggest paying attention to the following matters: 
1. Based on the conclusions above after conducting research and conducting test tests In the early stages of material preparation, especially fine aggregates, washed aggregates and already in SSD state, it should be placed in a place that can truly maintain SSD conditions until the aggregates are ready for use.

2. In order to get the right mixing further research needs to be done on the properties of lightweight concrete such as trial and error.

3. The method of making foam agent must be noticed and ensure that the foam produced is in accordance with the provisions.

4. Coconut shell should not be included in the mix design, coconut shell should be included in subsequent studies in a normal concrete mix design, because the coconut shell settles on the surface during the drying process in the cylinder.

5. It should be noted in the water content when using added ingredients such as additive additon $5 \mathrm{M}$, the accident rate on water is quite high.

\section{REFERENCES}

[1]. Angelina Eva Lianasari, (2003). Pengguana limbah bubur kertas dan fly ash pada Batako

[2]. Anugrah A, Mustaza. (2010). Beton Ringan dari Campuran Styrofoam dan Serbuk Gergaji dengan Semen Portland 250, 300, dan 350 kg/m3, Skripsi, Institut Teknologi. Surabaya.

[3]. Asroni, A., (2010), Kolom Fondasi Dan Balok T Beton Bertulang, Surakarta: Graha Ilmu.

[4]. Budiarto, Purwanto, (2016). Pemanfaatan Serutan Karet Ban Bekas Sebagai Subtitusi Pasir Silika pada Cellular Lightweight Concrete, Jurnal Riset. Kementrian Perindustrian Republik Indonesia.

[5]. Dirga, Darma (2014). Lightweight Concrete Making With Rubber Crumb

[6]. Dipohusodo, Istimawan.1996. Manajemen Proyek \& Konstruksi.Kanisius. Jogjakarta

[7]. Endarto, Zulfiar. (2010), Kajian Eksperimen Kuat Tekan Beton Ringan Menggunaan Agregat Bambu dan Bahan Tambah Beton, Universitas Muhammadiyah. Yogyakarta

[8]. Gunawan, Prayitno, Abdul Majid. (2013). Pengaruh Penambahan Serat Seng Pada Beton Ringan Dengan Teknologi Foam Terhadap Kuat Tekan, Kuat Tarik, dan Modulus Elastisitas, Skripsi, Universitas Sebelas Maret. Surakarta.

[9]. Gunawan, Wibowo, Mardiyanto. (2013). Pengaruh Penambahan Serat Aluminium Pada Beton Ringan Dengan Teknologi Foam Terhadap Kuat Tekan, Kuat Tarik dan Modulus Elastisitas, Skripsi, Universitas Sebelas Maret. Surakarta.

[10]. Halim, Hamid, 2016. "Tabel Perbandingan Komposisi Material Adukan Beton'[online].Tersedia:

[11]. Harjanto, Sony, Suharno, Ashadi (2007). Strukturmikro dan Sifat Fisik-MekanikBeton Ringan Tanpa Pematangan Dalam Autoclave (Non Autoclaved Aerated Concrete, $N A A C)$

[12]. Husin A, dan Setiadji R. 2008. Pengaruh Penambahan Foam Agent Terhadap Kualitas Bata Beton. Pusat Litbang Permukiman. Bandung

[13]. Jumiati, Masthura. (2018). Pembuatan Beton Ringan Berbasis Sampah Organik, Skripsi, Universitas Sumatera Utara. Medan.

[14]. Kurniawan D.S, Yuono. (2018). Compressive Strength Of Geopolymer Lightweight Concrete With Coparison Of Rice Husk Ash And Alkali Activator 50\%-50\% In Curing Time Variations, Skripsi. Tunas Pembangunan University Of Surakarta

[15]. Mita Sari, Imaduddin. (2018). Studi Penggunaan Catayst, Monomer, Fly Ash dan Penambahan Serat Polypropylene Sebagai Alternatif Pembuatan Beton Ringan Seluler, Skripsi. Universitas Negeri. Surabaya. 
[16]. Purwanto, (2011). Studi Kuat Lentur Beton Ringan Berserat Kawat Galvanis

[17]. Rustendi, Iwan, 2004. Pengaruh Penggunaan Tempurung Kelapa sebagai Material Serat Terhadap kuat tekan beton, Media Komunikasi Teknik Sipil Volume 12 No 2 Edisi XXIX bulan Juli

[18]. Rommel,Erwin. (2013). Pembuatan Beton Ringan dari Aggregat Buatan Berbahan Plastik, Skripsi. Universitas Muhammadiyah. Malang

[19]. Sebayang, Surya. 2010. Pengaruh Abu Terbang Sebagai Pengganti Sejumlah Semen Type V pada Beton Mutu Tinggi. Bandar Lampung : Universitas Lampung

[20]. SK SNI S-18-1990-03, 1990. Spesifikasi Tambahan Untuk Beton.

[21]. SNI 03-1972-1990, 1990. Metode Pengujian Slump Beton Semen Portland.

[22]. SNI 03-1972-1990, 1990. Metode Pengujian Slump.

[23]. SNI 7394:2008, Tabel Perbandingan Komposisi Material Adukan Beton

[24]. Sutaryono, Indra,2013 Pengaruh Penambahan Material Serat Tutup Botol (Crown Cork) Terhadap Kuat Tekan Dan Kuat Tarik Belah Beton Universitas Pendidikan Indonesia

[25]. Satyarno. (2004). Penggunaan Semen Puth untuk Beton Styrofoam Ringan (BATAFOAM). Seminar Nasional Program Swadaya Teknik Sipil FT UGM.

[26]. Suarnita, I Wayan,2010.Karakteristik Beton Ringan Dengan Munggunakan Tempurung Kelapa Sebagai Bahan Pengganti Agregat Kasar, Jurusan Teknik Sipil Fakultas Teknik Universitas TadulakoPalu

[27]. Standar ASTM. C.494 (1995: .254) Jenis dan definisi bahan tambah kimia

[28]. Surjani Wonorahardjo. 2010. Dasar-Dasar Sains. Jakarta : Indeks

[29]. Susanto, Widjaja, Antoni, Hardjito, (2006). Pembuatan Pasta Ringan Geopolimer Celluler Lightweight Concrete (CLC) Berbasis Campuran Lumpur Lapindo Sidoarjo dan Fly Ash

[30]. Sutikno. (2003). Menuju Pendidikan Bermutu. Mataram: NTP Press.

[31]. Tjokrodimuljo, K., 1996, Teknologi Beton, Jurusan Teknik Sipil, Fakultas Teknik Universitas Gadjah Mada, Yogyakarta

[32]. Wardi, 2003. Pengaruh Pemanfaatan Arang Batok Kelapa Terhadap Kuat Tekan Beton, Universitas Bung Hatta, Padang.

[33]. Widyawati, (2011). Studi Kuat Tekan Beton Ringan dengan Metoda Rancang Campur Dreux-Corrise

[34]. Yarman, Edy, 2010. Analisis Kuat Tekan Beton Menggunakan Agragat Kasar Cangkang Sawit, Tuugas Akhir, Jurusan Teknik Sipil, Fakultas Teknik, Universitas Pasir Pengaraian.

[35]. http://www.sentosamortar.com/2016/10/26/tabel-perbandingan-komposisi-materialcampuran-beton/

[36]. Syaiful. (2011). “Beton”. [online]. Tersedia: http://syaiful-beton.blogspot.co.id/ yang di rekam pada Nov 2011. [28 ovember 2017]

[37]. http://disbunaksulteng.com/ 